\title{
CONSERVATION BEHAVIOR OF PLANT BIODIVERSITY: SUPPORTING ENVIRONMENTAL SUSTAINABILITY
}

\author{
DIANA VIVANTI SIGIT*, RIZHAL HENDI RISTANTO AND SHAFIRA RAMADHANTY \\ ADITYANINGSIH
}

Biology Education, Universitas Negeri Jakarta, Rawamangun Muka Street, East Jakarta, Indonesia.

*Corresponding author: mdianav@unj.ac.id

Submitted final draft: 20 February 2021 Accepted: 11 March $2021 \quad$ http://doi.org/10.46754/jssm.2021.07.007

\begin{abstract}
This study describes the plant-biodiversity conservation behavior among natural science and social science university students. It was conducted using survey questionnaire techniques. The instrument in this study contained statements regarding conservation behavior towards plant biodiversity. The instrument indicator was based on the principle of Conservation Law No. 5 of 1990, namely: 1) Protection, 2) Preservation, and 3) Utilization. The instrument showed that all items were valid and reliable. The data was analyzed descriptively. The result indicated that students, in general, had good responses to plant-biodiversity conservation behavior. Plant-biodiversity conservation behavior was good, with natural science students more inclined towards it than social science students. University students also had the same average percentage in each of the conservation indicator. Conservation plant biodiversity is very important to be improved to preserve environmental sustainability. This research recommends that social science students must also learn about conservation behavior to support environmental sustainability.
\end{abstract}

Keywords: Biodiversity, conservation, plant.

\section{Introduction}

Indonesia is a country with substantial species diversity. However, there are many conservation problems, such as the high rate of plant species extinction. Some 240 species of plants have been declared rare while 36 species, especially trees, are known to be extinct (Kusmana \& Hikmat, 2015). This is due to s utilization rates proportional to the lack of public awareness of the importance of plant diversity (Fauzi \& Fariantika, 2018; Zhao et al., 2018). One of things that can overcome the problem of reduced plant biodiversity is conservation actions (Markaki, 2014). Conservation also needs to be developed among various groups not only in the form of knowledge but also in the form of action to maintain environmental sustainability (Avan et al., 2011; Komala et al., 2020; Rahmayanti, Ichsan, Azwar, Damayanti, et al., 2020; Suharini, Ariyadi, et al., 2020; Suharini, Kurniawan, et al., 2020).

Among those who still have many opportunities to practice plant diversity conservation are students. Students are a generation that is still very enthusiastic about environmental issues, so they are more likely to adopt behavior that promotes conservation (Avan et al., 2011). Although there are many opportunities, it is uncertain whether their attitude towards plant diversity conservation is put into action. Students have an important role to promote sustainability in their environment and teachers can facilitate with contextual lesson about the environment. This can improve students behavior to protect the biodiversity in environment (Azrai et al., 2019; Mamun et al., 2020; Sigit, Azrai, Setyawati, et al., 2019).

Several studies on efforts to protect the environment are often in terms of facilities and infrastructure (Miarsyah, Sigit, et al., 2019; Russo et al., 2016). arious technology-based learning media have also been developed to improve students' ability to overcome various environmental problems (Boholano, 2017; Ichsan et al., 2020; Miarsyah, Rusdi, et al., 2019; Purwanto et al., 2020; Saltan \& Divarci, 2017; Sigit, Azrai, Heryanti, et al., 2019). Another effort to improve students' ability and behavior in overcoming environmental problems $\mathrm{s}$ by developing an environment-based education 
model to empower environmental sustainability (Beattie, 2015; Rahmayanti, Ichsan, Azwar, Purwandari, et al., 2020; Sigit et al., 2020). One way of promoting plant diversity preservation is through the development of teaching materials on the concept of plant growth and development (Supriyatin et al., 2019). Various efforts have been made to empower students to overcome various science and environmental problems (Ichsan \& Rahmayanti, 2020; Komala et al., 2020; Paristiowati et al., 2019; Sahronih et al., 2019; Suryanda et al., 2020). Based on the discussion, the approach of this study is novel because students' conservation behavior in order to increase awareness of plant biodiversity has not been described. This research is urgent because there are many environmental problems to be solve, especially on conservation.

Given the low likelihood of students applying conservation behavior to plant biodiversity, a learning medium will be created about the introduction of plant diversity. Through adequate knowledge they can improve their behavior (Suryanda et al., 2020). Research on biodiversity mostly covers biological perspectives. There are not many studies, however, that discuss conservation behavior itself, especially in terms of natural science and social science students' point of view. The aim of this research was to analyze the students' conservation behavior and to compare these between natural science and social science students.

\section{Method}

This research was a descriptive study and conducted in April and May 2020. The samples were 200 undergraduate students consisting of 100 natural science (NS) and 100 social science (SS) students randomly selected from several universities in Jakarta studying in several programs. The questionnaire was administered through Google Forms. The instrument used multiple-choice and agree-disagree tests. The multiple-choice instrument contained statements regarding conservation behavior towards plant biodiversity, while the agree-disagree instrument contained statements that could measure the level of students' knowledge about plant biodiversity. The source of the instruments were derived from the conservation principles based on Law no. 5 of 1990 namely: 1) Protection, 2) Preservation, and 3) Utilization and an equivalent biodiversity concept for undergraduate students. The multiple-choice instruments were on a scale of 1-5 and the agree-disagree instrument were score 0 and 1 . ests on these instruments found them to be valid and reliable. The data of students' conservation behavior on plant biodiversity were analyzed descriptively using tables, whereas the differences between natural science (NS) and social science (SS) students were tested by the t-test.

\section{Results and Discussion}

he percentage of conservation behavior from natural science and social science students is shown in Table 1. The differences between the groups could be analyzed based on the table.

In Table 2, the conservation behavior percentage is presented, where it is found that natural science students have a higher percentage $(56.7 \%)$ than social science students $(46.3 \%)$. It meant that students from natural science involved better in the conservation behavior than social science students.

The differences between natural science and social science students were then analyzed statistically by t-test. The results indicated that the conservation behavior was significantly different between the two groups.

Referring to Table 4 the percentage of conservation behavior based on the three dimensions suggested that protection was a dimension with the highest percentage and followed by preservation and utilization.

Conservation behavior could also be discussed in terms of gender as shown in Table 5. Female students seemed to have higher score in conservation behavior $(81.66 \%)$ than male students $(71.14 \%)$. 
Table 1: Percentage of Conservation Behavior of Natural Science (NS) and Social Science (SS) Students

\begin{tabular}{clccc}
\hline $\begin{array}{c}\text { Number of } \\
\text { Item }\end{array}$ & \multicolumn{1}{c}{ Statement } & NS (\%) & SS (\%) & $\begin{array}{c}\text { Difference } \\
\text { (\%) }\end{array}$ \\
\hline 1 & Knowing plant's extinction status & 53.3 & 46.7 & 6.6 \\
2 & Supporting constitution about plant conservation & 52.8 & 47.2 & 5.6 \\
3 & Prohibiting someone who wants to destroy plants & 70.4 & 29.6 & 40.8 \\
4 & Giving criticism and suggestions to improve awareness & 52.7 & 47.3 & 5.4 \\
& of plants & & & \\
5 & Planting in own garden / home & 53.4 & 46.6 & 6.8 \\
6 & Sharing information about plant benefits & 54.8 & 45.2 & 9.6 \\
7 & Trying to protect plants & 52.2 & 47.8 & 4.4 \\
8 & Sharing information for protecting plants & 54.2 & 45.8 & 8.4 \\
9 & Active in plant conservation programs & 54.8 & 45.2 & 9.6 \\
10 & Introducing plant biodiversity to other & 55.2 & 44.8 & 10.4 \\
11 & Paying attention on everything about plant conservation & 66.8 & 33.2 & 33.6 \\
12 & Collecting unique plants & 66.4 & 33.6 & 32.8 \\
13 & Knowing the characteristics of some plants & 56.2 & 43.8 & 12.4 \\
14 & Following the rules about plant conservation & 68.6 & 31.4 & 37.2 \\
15 & Exploiting plants for own happiness & 68.7 & 31.2 & 37.5 \\
16 & Donating money for plant conservation & 53.9 & 46.1 & 7.8 \\
17 & Selecting the real sample of plant for study purposes & 69.1 & 30.9 & 38.2 \\
18 & Always contribute to help plant lives & 69.7 & 30.3 & 39.4 \\
19 & Always preserve and encourage plant conservation & 70.7 & 29.3 & 41.4 \\
\hline & actions & & & \\
\hline
\end{tabular}

Table 2: Percentage value of conservation behavior between university students

\begin{tabular}{lc}
\hline \multicolumn{1}{c}{ Group Category } & Percentage \\
\hline Natural Science & 56.7 \\
Social Science & 43.3 \\
\hline Total & 100 \\
\hline
\end{tabular}

This research also gained some data on students' opinions through a case statement and response with agree or disagree answer. The instrument statements were phrased so that disagreeing with them would be the "good" answer. Table 6 showed that students' choice on item number 1 and 2 with agree and disagree

Table 3: The t-test on The Comparison of Conservation Behavior between NS and SS Student

\begin{tabular}{lcccccc}
\hline & & & \multicolumn{3}{c}{$\begin{array}{l}\text { 95\% Confidence } \\
\text { Interval of the } \\
\text { Difference }\end{array}$} \\
\hline & & & & Men \\
& & & & Lower & Upper \\
NS & 133.755 & 99 & .000 & 78.630 & 77.46 & 79.80 \\
SS & 57.164 & 99 & .000 & 53.190 & 51.34 & 55.04 \\
\hline
\end{tabular}

$\mathrm{p}<0.05$ 
Table 4: Percentage of conservation behavior of plant biodiversity dimensions

\begin{tabular}{clc}
\hline No & \multicolumn{1}{c}{ Dimensions } & Percentage \\
\hline 1 & Protection & 36.82 \\
2 & Preservation & 30.89 \\
3 & Utilization & 32.28 \\
\hline Total & & 100 \\
\hline
\end{tabular}

Table 5: Comparison of Score between Female and Male's Conservation Behavior of Plant Biodiversity

\begin{tabular}{lcc}
\hline \multicolumn{1}{c}{ Gender } & Respondent & Mean Score \\
\hline Male & 100 & 71.14 \\
Female & 100 & 81.66 \\
\hline
\end{tabular}

Table 6: Number of Students on Case Statement (Agree-Disagree)

\begin{tabular}{clcc}
\hline No & \multicolumn{1}{c}{ Item } & $\begin{array}{c}\text { Agree } \\
\text { (person) }\end{array}$ & $\begin{array}{c}\text { Disagree } \\
\text { (person) }\end{array}$ \\
\hline 1 & Exchange of plants between countries can increase plant diversity. & 146 & 54 \\
2 & $\begin{array}{l}\text { The habit of consumption of rice as a staple food is an effort to } \\
\text { maintain the presence of rice plants. }\end{array}$ & 144 & 155 \\
3 & $\begin{array}{l}\text { The herbal medicine industry is actually less profitable because it } \\
\text { takes a long time to work and requires large area to grow }\end{array}$ & 45 & 181 \\
$4 \quad \begin{array}{l}\text { Rare plants are not a great concern as now we can learn through } \\
\text { virtual learning media through computers }\end{array}$ & 19 & 170 \\
5 & $\begin{array}{l}\text { Horticultural plants that do not sell on the market do not need to be } \\
\text { preserved because they are unprofitable and cost a lot of money to } \\
\text { preserve. }\end{array}$ & 30 & 165 \\
\hline & $\begin{array}{l}\text { Green open spaces were subdued by flats development as houses } \\
\text { along the riverbank were also very important }\end{array}$ & 35 & \\
\hline
\end{tabular}

response. This result showed that for problem number 1 and 2, students missed the concept of biodiversity.

Table 7 showed that although item number 1 and 2 were not well responded, all items obtained a similar percentage. There were no items with an extreme percentage among the six problems in conservation behavior.

Based on the agree-disagree instrument the data were analyzed in two categories. In Table 8 , it was found that students with good conservation behavior (58.5\%) were higher than the fair group (41.5\%). This was a good result as it indicated that students in university have good opinions on conserving plant biodiversity.

The percentage of conservation behavior in each statement of the instrument was shown in Table 1. In every statement, the percentage of NS students was higher than those of the SS students. This result was really reasonable since NS students received lessons on plant biodiversity and the concept of conservation from senior high school, while SS students did not. Social science students obtained this information from news and social media. In addition, NS students were more active in preserving the environment than SS students (Azrai et al., 2019; Ichsan \& Rahmayanti, 2020). 
Table 7: Percentage of Item on Case Statement (Agree-Disagree)

\begin{tabular}{clc}
\hline No & \multicolumn{1}{c}{ Item } & Percentage \\
\hline 1 & $\begin{array}{l}\text { Exchange of plants between countries can increase plant diversity. } \\
2\end{array}$ & $\begin{array}{l}\text { The habit of consumption of rice as a staple food is an effort to maintain the } \\
\text { presence of rice plants. }\end{array}$ \\
3 & $\begin{array}{l}\text { The herbal medicine industry is actually less profitable because it takes a long } \\
\text { time to work and requires large area to grow }\end{array}$ & 16.9 \\
4 & $\begin{array}{l}\text { Rare plants are not a great concern as now we can learn through virtual learning } \\
\text { media through computers }\end{array}$ & 16.5 \\
5 & $\begin{array}{l}\text { Horticultural plants that do not sell on the market do not need to be preserved } \\
\text { because they are unprofitable and cost a lot of money to preserve. } \\
\text { Green open spaces were subdued by flats as houses along the riverbank were } \\
\text { also very important }\end{array}$ & 16.9 \\
\hline Total & & 17.0 \\
\hline
\end{tabular}

Table 8: Percentage of Category on Conservation Behavior of Plant Biodiversity (Agree-disagree)

\begin{tabular}{|c|c|c|}
\hline Category & Total University Students & Percentage \\
\hline Fair & 83 & 41.5 \\
\hline Good & 117 & 58.5 \\
\hline Total & 200 & 100 \\
\hline
\end{tabular}

Of all the instruments, several of them had huge differences between NS and the SS students. The instruments with the most differences were numbers 3 and 19, which was about $40 \%$ to $41 \%$. The result of item number 4 suggested that NS students tended to be more active in reprimanding others in the destruction of plants compared to SS students. This was due to several factors, including the fact that NS students tended to have the desire to get public attention for conservation issues. This is different to SS students' tendency to apply conservation only to themselves (Seechaliao, 2017; Uzun, 2012). Another supporting factor was a sense of connectedness with the environment that was higher among the NS students, so they have more desire to influence others to respect the environment. This is important because university students must advocate to keep environmentalism in the community. It is relevant with statement number 19 that NS students can be more active to influence and promote some activities to preserve plant biodiversity. In addition, SS
Students tended to be more comfortable to contribute to preserving the environment by themselves without having to influence others to support environmental sustainability (Djamahar et al., 2019; Kamerilova et al., 2016; Purwanto et al., 2020; Rahmayanti, Ichsan, Oktaviani, Syani, et al., 2020).

Other instruments with a substantial difference in value point included numbers 14 , 15,17 , and 18 . The differences were about $37.2 \%$ to $39.4 \%$. For the statements in number 15 and 17 about "Using plants for one's own needs", NS students tended to have more contribution than SS students. This result represented some contradictions with previous discussion stating that NS students had more awareness of the environment than SS students. However, NS students often use the environment as their main subject of study and this creates a dilemma for them (Sigit et al., 2020). For example, (according to statement number 17), NS students often picked living plants for their research and study. It is unavoidable and legal. This action will encourage NS students to be more aware in 
preserving their own environment, especially for plant biodiversity (Ichsan et al., 2019). This led to statements number 18 that NS students did more to contribute to saving plants' lives than SS students with a difference of $39.4 \%$.

The differences in the percentage of student scores between the NS students and SS students were presented in Table 2. It can be seen that the percentage of conservation behavior of plant biodiversity was higher among NS students, amounting to $56.7 \%$. This can be influenced by the type of natural science knowledge possessed by the NS students.. This could influence the students' sensitivity in preserving the environment, one of which is to preserve plants (Suryanda et al., 2020). In addition, NS students also had more understanding about the conservation and awareness of the impact of human actions on other living things. Nevertheless, it does not mean that SS students are less sensitive to the environment, it's just that the scope of their learning is more directed towards humanity so that sensitivity to the environment is not as good as the NS students (Bela et al., 2016).

The differences of conservation behavior among NS and SS students was statistically analyzed by using the t-test as shown in Table 3 . The result showed a significant difference between NS and SS students in their conservation behavior. This was related to a statement about NS and SS that always has differences in their score regarding the environment, especially preservation actions, such as promoting environmentalism on social media and joining environmental organizations (Bidegain et al., 2019).

The percentage of each dimension showed some differences as seen in Table 4. The results suggested that the dimension with the highest percentage was "Protection",36.82\%. The protection dimension includes efforts to protect the diversity of plants that the students see in the environment. In general, communities tend to be more capable of carrying out conservation efforts in the form of protection, because this effort is the easiest way to do it. For example, when someone finds a unique plant around them, the tendency not to damage the plant would always appear. It also prevails among the students who tend to be more sensitive to the environment, they would maintain the presence of plants to support environmental sustainability (Supriyatin et al., 2019). The other dimensions were preservation $(30.89 \%)$ and utilization (32.28\%), that had similar percentages, which were lower than the protection dimension as students were not actively involved in these dimensions.

In addition to the comparison of the dimensions between NS and SS students, their conservation behavior was also compared based on gender (Table 5). The score of conservation behavior of plant biodiversity of female students was higher than male students. This is assumed to be related to females being more sensitive to the environment than males. For example, when a woman finds some plants outdoors, she would take care of them and try her best not to harm them. The other reason was women were generally more concerned about the environment because they express greater concern over potential environmental risks than men (Aprile \& Fiorillo, 2017; Braun et al., 2018; Runhaar et al., 2019).

This study also tried to identify students' opinion on some cases of plant biodiversity using agree-disagree opinion. There were 6 statements related to the concept of plant biodiversity that should be answered by a disagree answer. As seen in Table 6, items number 1 and 2 that seemed to be not a good answer since students responded with "agree". It showed that some people still misunderstand plant biodiversity. In item number 1, "exchange of plants between countries can increase plant diversity", seems to be good, but people have to be careful since the exchanged plant might be invasive and could be harmful to the native species. For example, in item number 2, more than half of respondents chose the "agree" opinion, Indonesians eat rice as their daily staple food, and they think this is a great way to preserve the existence of rice (Oryza sativa L.) species. However, there is a 
statement that the existence of biodiversity can support food production (Hooykaas et al., 2020). It means that the habits of people who always consume one species of staple food do not help in improving biodiversity; moreover, it causes "homogeneity" and reduces biodiversity. The respondents, however, on average, still have a good grasp about plant biodiversity indicated by their "disagree" answer for item 3, 4, 5, and 6.

In table 7 , the percentage of the answers showed a similar number; thus, there was no difference in each item. In addition to the biodiversity plant instrument, the respondent category was in a good category, which means that their understanding of the biodiversity of plants was good. The introduction of plant biodiversity to the general public has a good impact (Ichsan et al., 2020). Especially for students, their access to information, tends to allow them to have critical thinking and support environmental sustainability (Angelaina \& Jimoyiannis, 2012; Orozco \& Yangco, 2016).

Table 8 showed the results of the percentages of conservation behavior of plant biodiversity values. This result showed students' excellent ability to obtain information about plant biodiversity to improve their knowledge (Camacho \& Legare, 2015; Cukurova \& Bennett, 2018; Kivunja, 2015). Therefore, high self-awareness in terms of conservation behavior from university students also increases. Through the information they obtain, certain behaviors will be inculcated to meet the needs based on the generated information. Moreover, university students are a group of high-level students so that the process of digesting information will be easier. The process of critical thinking also influences the act of applying practice directly to daily life (Fitzpatrick \& Schulz, 2015; Garcia, 2015).

\section{Conclusion}

Attitudes towards plant biodiversity among university students was in a good category, thus the conservation behavior of plants was also good. There were differences between students in the natural science group and social science group. The natural science group had better biodiversity conservation behavior of plants than the social science group. University students also had the same average result in the conservation indicator and the students, in general, had good responses to plant-biodiversity conservation behavior. It is important to improve conservation behavior of plant biodiversity to preserve environmental sustainability. We recommend that conservation behavior be developed for natural science and social science students, due to the ongoing biodiversity loss and environmental degradation. Activity planning in conservation behavior as well as the implementation in school and universities might be a compulsory program to reach environmental sustainability. This study faced some limitations in the sample that only covered limited categories of students; therefore, another research with a large sampling might be a solution. We suggest development of learning media about conservation for students in school and university. Implications of this research for the future are schools and universities improving their curriculum and syllabus based on environmental conservation programs.

\section{Acknowledgements}

Authors wish to thank reviewers and editors for the constructive comments and not forgetting the university for the research opportunity.

\section{References}

Angelaina, S., \& Jimoyiannis, A. (2012). Analysing students' engagement and learning presence in an educational blog community. Educational Media International, 49(3), 183-200. https://doi. org/10.1080/09523987.2012.738012

Aprile, M. C., \& Fiorillo, D. (2017). Water conservation behavior and environmental concerns: evidence from a representative sample of Italian individuals. Journal of Cleaner Production. https://doi. org/10.1016/j.jclepro.2017.05.036 
Avan, C., Aydinli, B., Bakar, F., \& Alboga, Y. (2011). Preparing Attitude Scale to Define Students' Attitudes about Environment, Recycling, Plastic and Plastic Waste. International Electronic Journal of Environmental Education, 1(3), 179-191. https://dergipark.org.tr/en/pub/iejeegreen/ issue/7905/104039

Azrai, E. P., Sigit, D. V., Heryanti, E., Ichsan, I. Z., Jajomi, Y. P., \& Fadrikal, R. (2019). Green consumerism among students: A survey in campus. Journal of Physics: Conference Series, 1317(1), 012200. https:// doi.org/10.1088/1742-6596/1317/1/012200

Beattie, A. E. (2015). A Young Child's Perspectives on Outdoor Play: A Case Study from Vancouver, British Columbia. International Journal of Early Childhood Environmental Education, 3(1), 38-53.

Bela, G., Peltola, T., Young, J. C., Balázs, B., Arpin, I., Pataki, G., Hauck, J., Kelemen, E., Kopperoinen, L., Van Herzele, A., Keune, H., Hecker, S., Suškevičs, M., Roy, H. E., Itkonen, P., Külvik, M., László, M., Basnou, C., Pino, J., \& Bonn, A. (2016). Learning and the transformative potential of citizen science. Conservation Biology: The Journal of the Society for Conservation Biology, 30(5), 990-999. https://doi. org/10.1111/cobi.12762

Bidegain, I., Cerda, C., Catalán, E., Tironi, A., \& López-Santiago, C. (2019). Social preferences for ecosystem services in a biodiversity hotspot in South America. PLoS ONE, 14(4), 1-26. https://doi. org/10.1371/journal.pone.0215715

Boholano, H. B. (2017). Smart social networking: 21st century teaching and learning skills. Research in Pedagogy, 7(1), 21-29. https://doi.org/10.17810/2015.45

Braun, T., Cottrell, R., \& Dierkes, P. (2018). Fostering changes in attitude, knowledge and behavior: demographic variation in environmental education effects. Environmental Education Research, 24(6),
899-920. https://doi.org/10.1080/13504622 .2017.1343279

Camacho, D. J., \& Legare, J. M. (2015). Opportunities to create active learning techniques in the classroom. Journal of Instructional Research, 4, 38-45.

Cukurova, M., \& Bennett, J. (2018). Students' knowledge acquisition and ability to apply knowledge into different science contexts in two different independent learning settings. Research in Science and Technological Education, 36(1), 17-34. https://doi.org/10. 1080/02635143.2017.1336709

Djamahar, R., Ristanto, R. H., Sartono, N., Ichsan, I. Z., Darmawan, E., \& Muhlisin, A. (2019). Empowering Student's Metacognitive Skill through Cirsa Learning. Journal of Physics: Conference Series, 1227(1), 012001. https:// doi.org/10.1088/1742-6596/1227/1/012034

Fauzi, A., \& Fariantika, A. (2018). Courses perceived difficult by undergraduate students majoring in biology. Biosfer: Jurnal Pendidikan Biologi, 11(2), 7889. https://doi.org/10.21009/biosferjpb. v11n2.78-89

Fitzpatrick, B., \& Schulz, H. (2015). Do Curriculum Outcomes and Assessment Activities in Science Encourage Higher Order Thinking? Canadian Journal of Science, Mathematics and Technology Education, 15(2), 136-154. https://doi.org/ 10.1080/14926156.2015.1014074

Garcia, L. C. (2015). Environmental science issues for higher-order thinking skills (hots) development: A case study in the Philippines. In Biology Education and Research in a Changing Planet (pp. 45-54). https://doi.org/10.1007/978-981-287-524-2

Hooykaas, M. J. D., Schilthuizen, M., \& Smeets, I. (2020). Expanding the role of biodiversity in laypeople's lives: The view of communicators. Sustainability (Switzerland), 12(7), 1-25. https://doi. org/10.3390/su12072768 
Ichsan, I. Z., \& Rahmayanti, H. (2020). HOTSEP: Revised Anderson's Taxonomy in environmental learning of COVID-19. European Journal of Educational Research, 9(3), 1257-1265. https://doi.org/10.12973/ eu-jer.9.3.1257

Ichsan, I. Z., Sigit, D. V., Miarsyah, M., Ali, A., Arif, W. P., \& Prayitno, T. A. (2019). HOTS-AEP: Higher order thinking skills from elementary to master students in environmental learning. European Journal of Educational Research, 8(4), 935-942. https://doi.org/10.12973/eu-jer.8.4.935

Ichsan, I. Z., Sigit, D. V., Miarsyah, M., Ali, A., Suwandi, T., \& Titin, T. (2020). Implementation supplementary book of green consumerism: improving students' hots in environmental learning. European Journal of Educational Research, 9(1), 227-237. https://doi.org/10.12973/eujer.9.1.227

Kamerilova, G. S., Kartavykh, M. A., Ageeva, E. L., Veryaskina, M. A., \& Ruban, E. M. (2016). Electronic informational and educational environment as a factor of competence-oriented higher pedagogical education in the sphere of health, safety and environment. International Journal of Environmental and Science Education, 11(13), 6185-6194.

Kivunja, C. (2015). Teaching students to learn and to work well with 21 st century skills: Unpacking the career and life skills domain of the new learning paradigm. International Journal of Higher Education, 4(1), 1-11. https://doi.org/10.5430/ijhe.v4n1p1

Komala, R., Lestari, D. P., \& Ichsan, I. Z. (2020). Group investigation model in environmental learning: An effect for students' higher order thinking skills. Universal Journal of Educational Research, 8(4A), 9-14. https:// doi.org/10.13189/ujer.2020.081802

Kusmana, C., \& Hikmat, A. (2015). The Biodiversity of Flora in Indonesia. Journal of Natural Resources and Environmental
Management, 5(2), 187-198. https://doi. org/10.19081/jps1.5.2.187

Mamun, A. A., Fazal, S. A., Masud, M. M., Selvachandran, G., Zainol, N. R., \& Gai, Q. S. (2020). The Underlying Drivers of Underprivileged Households' Intention and Behavior towards Community Forestry Management: A Study Using Structural Equation Modelling and Artificial Neural Network Approach. Sustainability, 12(18), 7330 .

Markaki, V. (2014). Environmental Education through Inquiry and Technology. Science Education International, 25(1), 86-92.

Miarsyah, M., Rusdi, R., Aryani, N. D., \& Ichsan, I. Z. (2019). MEBA: Development androidbased ecosystem module for senior high school students. Indian Journal of Public Health Research and Development, 10(8), 2114-2118. https://doi.org/10.5958/09765506.2019 .02168 .5

Miarsyah, M., Sigit, D. V, Ichsan, I. Z., Fadrikal, R., \& Suprapto, M. (2019). Lekersmulia: Improving Indonesian students' environmental responsibility using multimedia in environmental learning. International Journal of Scientific and Technology Research, 8(12), 1639-1643. http://www.ijstr.org/final-print/dec2019/ Lekersmulia-Improving-IndonesianStudents-Environmental-ResponsibilityUsing-Multimedia-In-EnvironmentalLearning.pdf

Orozco, J. A., \& Yangco, R. T. (2016). Problembased learning: effects on critical and creative thinking skills in biology. Asian Journal of Biology Education, 9, 1-10.

Paristiowati, M., Hadinugrahaningsih, T., Purwanto, A., \& Karyadi, P. A. (2019). Analysis of students' scientific literacy in contextual-flipped classroom learning on acid-base topic. Journal of Physics: Conference Series, 1156(1), 012026. https:// doi.org/10.1088/1742-6596/1156/1/012026 
Purwanto, A., Ichsan, I. Z., Gomes, P. W. P., Rahman, M. M., \& Irwandani, I. (2020). ESBOR during COVID-19: Analysis students attitude for develop 21 st century environmental learning. Journal of Sustainability Science and Management, 15(7), 20-29. https://doi.org/10.46754/ jssm.2020.10.003

Rahmayanti, H., Ichsan, I. Z., Azwar, S. A., Damayanti, S., Suharini, E., \& Kurniawan, E. (2020). Environmental learning about flood disaster in university: Students HOTS for preliminary analysis to develop DIFMOL model. E3S Web of Conferences, 211, 02016. https://doi.org/10.1051/ e3sconf/202021102016

Rahmayanti, H., Ichsan, I. Z., Azwar, S. A., Purwandari, D. A., Pertiwi, N., Singh, C. K. S., \& Gomes, P. W. P. (2020). DIFMOL: Indonesian students' Hots and environmental education model during COVID-19. Journal of Sustainability Science and Management, 15(7), 10-19. https://doi.org/10.46754/jssm.2020.10.002

Rahmayanti, H., Ichsan, I. Z., Oktaviani, V., Syani, Y., Hadi, W., \& Marhento, G. (2020). Environmental attitude for smart city technology: Need assessment to develop smart trash in environmental education. International Journal of Advanced Science and Technology, 29(3), 8374-8383. http:// sersc.org/journals/index.php/IJAST/article/ view/9872

Runhaar, P., Wagenaar, K., Wesselink, R., \& Runhaar, H. (2019). Encouraging Students' Pro-environmental Behaviour: Examining the Interplay Between Student Characteristics and the Situational Strength of Schools. Journal of Education for Sustainable Development, 13(1), 45-66. https://doi.org/10.1177/0973408219840544

Russo, F., Rindone, C., \& Panuccio, P. (2016). European plans for the smart city: from theories and rules to logistics test case. European Planning Studies, 24(9), 1709-
1726. https://doi.org/10.1080/09654313.20 16.1182120

Sahronih, S., Purwanto, A., \& Sumantri, M. S. (2019). The effect of interactive learning media on students' science learning outcomes. ACM International Conference Proceeding Series, 20-24. https://doi. org/10.1145/3323771.3323797

Saltan, F., \& Divarci, O. F. (2017). Using Blogs to Improve Elementary School Students' Environmental Literacy in Science Class. European Journal of Educational Research, 6(3), 347-355. https://doi.org/10.12973/eujer.6.3.347

Seechaliao, T. (2017). Instructional strategies to support creativity and innovation in education. Journal of Education and Learning, 6(4), 201-208. https://doi. org/10.5539/jel.v6n4p201

Sigit, D. V., Azrai, E. P., Heryanti, E., Ichsan, I. Z., Jajomi, Y. P., \& Fadrikal, R. (2019). Development green consumerism e-book for undergraduate students (gc-ebus) as learning media in environmental learning. Indian Journal of Public Health Research and Development, 10(8), 2026-2031.https:// doi.org/10.5958/0976-5506.2019.02152.1

Sigit, D. V., Azrai, E. P., Setyawati, D. N., \& Ichsan, I. Z. (2019). Environmental literacy of biology undergraduate students in Jakarta: Profile and comparative analysis. Journal of Physics: Conference Series, 1402(3), 033048. https://doi.org/10.1088/17426596/1402/3/033048

Sigit, D. V., Miarsyah, M., Komala, R., Suryanda, A., Ichsan, I. Z., \& Fadrikal, R. (2020). EECN: Analysis, potency, benefit for students knowledge and attitude to conserve mangroves and coral reefs. International Journal of Instruction, 13(1), 125-138. https://doi.org/10.29333/ iji.2020.1318a

Suharini, E., Ariyadi, M. H., \& Kurniawan, E. (2020). Google earth pro as a learning media for mitigation and adaptation of 
landslide disaster. International Journal of Information and Education Technology, 10(11), 820-825.

Suharini, E., Kurniawan, E., \& Ichsan, I. Z. (2020). Disaster Mitigation Education in the COVID-19 Pandemic: A Case Study in Indonesia. Sustainability (United States), 13(6), 292-298. https://doi.org/10.1089/ sus. 2020.0053

Supriyatin, S., Rahayu, S., Ristanto, R. H., \& Ichsan, I. Z. (2019). Improving HOTS in Biology Learning: A Supplement Book of Plant Growth and Development. Universal Journal of Educational Research, 7(12), 2642-2646.

Suryanda, A., Azrai, E. P., Nuramadhan, M., \& Ichsan, I. Z. (2020). Analogy and critical thinking skills: Implementation learning strategy in biodiversity and environment topic. Universal Journal of Educational Research, 8(4A), 45-50. https://doi. org/10.13189/ujer.2020.081807

Uzun, N. (2012). A sample of active learning application in science education: The thema "cell" with educational games. Procedia - Social and Behavioral Sciences, 46, 2932-2936. https://doi.org/10.1016/j. sbspro.2012.05.592

Zhao, J., Lin, L., Sun, J., Zheng, X., \& Yin, J. (2018). Students' engagement in a science classroom: Does knowledge diversity matter? Journal of Educational Research, 111(6), 756-763. https://doi.org/10.1080/0 0220671.2018 .1427036 